\title{
Evaluation of Burnout Syndrome Prevalence in Medical Students
}

\section{Avaliação da Prevalência da Síndrome de Burnout em Estudantes de Medicina}

\author{
Camila Serra Rodrigues ${ }^{I}$ (I) \\ Márcia Luísa Albuquerque de Deus ${ }^{I}$ (iD \\ Flávia Teixeira de Andrade ${ }^{I}$ (D) \\ Giovanna Breda Rezende ${ }^{I}$ (D) \\ Lucas de Ávila Mariano ${ }^{I}(\mathbb{D}$ \\ Alexandre Brandão $\operatorname{Sé}^{I} \mathbb{D}$
}

\section{KEYWORDS}

- Medical Students.

- Student's Health.

- Professional Burnout.

Introduction: Burnout Syndrome (BS) is related to chronic occupational stress, present in the life of medical students. This syndrome comprises three basic dimensions: I- emotional exhaustion; II- increased mental distancing from the work itself or feelings of negativism and cynicism related to the work itself; and III reduced professional effectiveness. This study aims to assess the prevalence, risk factors for the development and symptoms associated with Burnout Syndrome in medical students from a district college, in addition to establishing a profile of students with a higher risk of having a BS diagnosis. Method: This is a cross-sectional observational study. The Maslach Burnout Inventory (MBI) - Student Survey questionnaire, specific version for students, which is a questionnaire of sociodemographic factors, one of predictive factors and another of possible somatic symptoms associated with BS were applied. The sample was obtained by convenience and its representativeness was calculated in relation to the total number of students. A student was considered to be at moderate or high risk of developing BS when they had one or two altered BS dimensions, respectively. Results: $67.11 \%$ of the total students regularly enrolled from the $1^{\text {st }}$ to the $6^{\text {th }}$ year of the medical course answered the questionnaires. Of the total sample, $80.63 \%$ of male students and $81.06 \%$ of female students were identified as having a high or moderate risk for BS. The sociodemographic factors associated with the risk of developing BS were: age, who the student lives with, having children and doing paid work. The most statistically significant predictor was the self-management of tasks proposed by the Medical School. Conclusion: The prevalence of high risk and diagnosis of BS found among medical students was $26.44 \%$ and $3.95 \%$, respectively. Differences were identified between the high-risk profiles for female and male students. 


\section{RESUMO}

\section{PALAVRAS-CHAVE}

- Estudantes de Medicina

- Saúde do Estudante.

- Esgotamento Profissional.

Introdução: A síndrome de burnout (SB) está relacionada ao estresse ocupacional crônico, presente na vida do acadêmico de Medicina. Essa síndrome compreende três dimensões básicas: 1. exaustão emocional; 2. aumento do distanciamento mental do próprio trabalho ou sentimentos de negativismo e cinismo relacionados ao próprio trabalho; e 3. redução da eficácia profissional. Este estudo teve como objetivos identificar a prevalência da SB, os fatores de risco para o desenvolvimento da síndrome e os sintomas associados a ela em estudantes de Medicina de uma faculdade distrital, e estabelecer um perfil de discentes com maior risco de apresentar diagnóstico de SB. Método: Trata-se de um estudo observacional transversal. Foram aplicados o Maslach Burnout Inventory - Student Survey (MBI-SS), versão específica para estudantes, um questionário de fatores sociodemográficos, um de fatores preditores e outro de possíveis sintomas somáticos associados à SB. Obteve-se o universo amostral por conveniência, e calculou-se sua representatividade diante do total de estudantes. Foi considerado como moderado ou de alto risco o estudante que apresentou uma ou duas dimensões da SB alteradas, respectivamente. Resultados: Do total de estudantes regularmente matriculados do primeiro ao sexto ano do curso de Medicina, $67,11 \%$ responderam aos questionários. Da amostra total, 80,63\% estudantes do gênero masculino e $81,06 \%$ dos estudantes do gênero feminino foram identificados como de alto ou moderado risco para SB. Os fatores sociodemográficos associados ao risco de desenvolvimento de SB foram: idade, com quem reside, possuir filhos e realizar trabalho remunerado. Já o fator preditor com maior relevância estatística foi o autogerenciamento de tarefas propostas pela faculdade. Conclusão: As prevalências de alto risco e diagnóstico de SB encontradas entre os estudantes de Medicina foram 26,44\% e 3,95\%, respectivamente. Identificaram-se diferenças entre os perfis de alto risco para os gêneros feminino e masculino.

Received on 2/12/20

Accepted on 10/16/20

\section{INTRODUCTION}

The mental health of medical students is an important aspect to be considered in medical education. When there is no psychological balance, there is a greater tendency to depression, drug use, suicide and occupational dysfunction. This imbalance can lead to a condition known as Burnout Syndrome (BS) ${ }^{1}$.

Burnout Syndrome was recognized as an occupational phenomenon and included in the International Classification of Diseases (ICD-11), approved by the $72^{\text {nd }}$ World Assembly of the World Health Organization. This disease comprises three basic aspects: I-emotional exhaustion; IIincreased mental distancing from the work itself or feelings of negativism and cynicism related to the work itself; and III - reduced professional effectiveness ${ }^{2}$. Additionally, this syndrome is associated with chronic occupational stress, present in student life. The main symptoms presented by the affected individuals are physical (constant and progressive fatigue, sleep disorders, difficulty in relaxing, immunodeficiency, headache); psychological (difficulty concentrating, anxiety, depression) and behavioral (disinterest, tendency to isolation and neglect) ${ }^{3}$.

The development of this syndrome among students is essentially due to long academic hours, untimely work in health services, less time for leisure, friends and family, added to the great social expectation related to the medical career ${ }^{4,5}$. Such individuals are therefore more vulnerable to mental health and academic life damage. According to a study carried out in five universities in Peru, approximately $20 \%$ of medical students from these institutions have $\mathrm{BS}^{6}$.

Another aspect to be addressed is the student's quality of life, which can prevent or result in BS. Quality of life is a comprehensive concept that is difficult to measure, which is defined based on the individual's perception regarding their culture, values, social environment, expectations and experienced concerns. It may include physical, psychological and mental health ${ }^{7}$. The student's quality of life should promote academic commitment and a positive mental status, which are important factors for learning, as opposed to $\mathrm{BS}^{8}$.

This study aimed to assess the prevalence and risk factors for BS development, as well as the symptoms associated with BS in undergraduate medical students from a public college in the Federal District (DF), Brazil, in addition to establishing a profile of the students most likely to have a diagnosis of BS.

\section{METHODS}

- Typification: This is a cross-sectional, observational study that identified the prevalence of Burnout Syndrome in undergraduate medical students from Escola Superior de Ciências da Saúde (ESCS), a public college in the Federal District that uses an active methodology known as Problem-Based Learning (PBL). Moreover, data were collected on the participants' sociodemographic profile, the predictive factors for BS and the symptoms related to BS reported by the students.

- Instruments: For this assessment, the sociodemographic and somatic symptom questionnaires and the Maslach Burnout Inventory (MBI) - Student Survey ${ }^{9,10}$, a specific version for students, were applied, which have been translated into and validated for the Portuguese language. The MBI was translated into Portuguese and validated by Campos and Maroco (2012) ${ }^{9}$ after the author's consent was obtained for its use. Subsequently, the translated version was compared with the original version in English and adaptations were made by the authors themselves for better understanding by the Brazilian population. The right to use and publish the Maslach Burnout Inventory instrument 
was acquired through payment of the license to reproduce the questionnaire to the owner of the scale, Mind Garden Publishers, Inc. The MBI consists of 22 items that assess the three basic dimensions of BS: emotional exhaustion, depersonalization and personal fulfillment ${ }^{3}$. The scoring of all assessed items uses a Likert-type scale that ranges from zero to six, being: (0) never, (1) a few times a year, (2) once a month or less, (3) a few times a month, (4) once a week, (5) a few times a week, (6) every day.

The sociodemographic questionnaire included the following data: gender, marital status, residence, year in college, paid work, justified absences in the last 30 days, effective periods of rest in the last 12 months, leisure activity in the free time and practice of physical exercise.

Students were asked about the presence of the following somatic symptoms commonly associated with exposure to chronic stress ${ }^{11}$ : headaches, easy irritability, loss or excess of appetite, high blood pressure, shoulder or neck pain, chest pain, sleeping difficulties, mental exhaustion, sexual difficulties, feeling there is no time for oneself, generalized fatigue, symptoms associated with minor infections, increased consumption of alcohol, cigarettes or chemical substances, difficulty in memory and concentration, gastrointestinal problems, allergic problems, feeling continuously rushed, feeling unwilling to start anything, loss of sense of humor, flu and colds and loss of sexual desire.

After responding to previous instruments, students also completed a questionnaire to assess the predictive factors that constitute risk factors for the development of BS, according to Loureiro et al. and Mejia et $\mathrm{al}^{4,5}$. The predictive factors were:

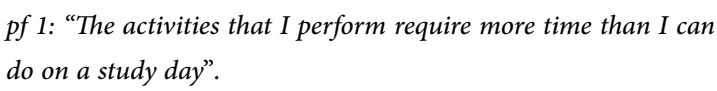
accurate diagnoses, achieved educational objectives, hours of study and extracurricular activities performed by the students".

pf 4: "I realize that in the institution where I study the principal, coordination, teachers are sensitive to students, that is, they value and recognize the developed work, and they also invest in and encourage the professional development of their students".

- Data analysis: Through the assessment of the scores obtained in the MBI, the diagnosis of Burnout Syndrome was attained and the groups at greatest risk for the disease were identified.

Each MBI dimension was assessed separately. For the dimension to be considered altered, the student must have a score greater than the $66^{\text {th }}$ percentile in the emotional exhaustion and depersonalization dimensions and lower than the $33^{\text {rd }}$ percentile in the personal achievement dimension ${ }^{12}$. Four criteria were established for each gender, aiming to classify the risk of students to develop Burnout Syndrome:

1. No altered dimensions: $\mathrm{CR} 0(\mathrm{~F})$ for females and CR0(M) for males, considered as low risk for BS.

2. One altered dimension: CR1(F) for females and CR1(M) for males, considered as moderate risk for BS.

3. Two altered dimensions: CR2(F) for females and CR2(M) for males, considered as high risk for BS.

4. Three altered dimensions: CR3(F) for females and CR3(M) for males, considered a diagnosis of BS.

The analysis of the main components was performed using the $\mathrm{R}$ statistical environment software (Cran $\mathrm{R}$ version 3.6.0) ${ }^{13}$.

- Diagnosis and risk classification: The concomitant presence of the 3 altered dimensions - emotional exhaustion, depersonalization and personal fulfillment (the latter dimension is an inverse one) constitutes a diagnosis of Burnout Syndrome. The risk classification for having the disease is based on the number of altered dimensions that constitute the syndrome ${ }^{11}$. In this study, the presence of two altered dimensions is considered as high risk for BS.

- Sampling: First, the authorization and support from the management responsible for the institution and the coordination of each year of the course at the college were obtained. Students between the $1^{\text {st }}$ and the $6^{\text {th }}$ year of the undergraduate medical course at ESCS were included. The questionnaires were applied between August and September 2018 and were answered by students during a regular school day. The sample was obtained for convenience, being considered representative by the Glauber Eduardo de Oliveira online calculator ${ }^{14}$. All students present at school on the days of questionnaire application and who agreed to participate in the study were included. Students who refused to complete the questionnaire, did not return it, were not present on the days of questionnaire application or those who did not complete it fully were excluded.

A total of 353 questionnaires were collected, from the $1^{\text {st }}$ to the $6^{\text {th }}$ years of the medical course, which represents a response rate of $67.11 \%$. As some answers were left blank, only the questionnaires that were adequately filled out were considered valid, due to the need to obtain all the answers for the evaluation of the 3 dimensions of BS in each participant using the MBI-SS, totaling 329 questionnaires, representing $62.55 \%$ of the ESCS medical students. The questionnaires were distributed together with the Free and Informed Consent (FIC) form individually to all research participants and the individual data were kept confidential.

- Ethics: As this is a study involving human beings, it was submitted to and approved by the Ethics Committee for Research Involving Human Beings, of Fundação de Ensino e Pesquisa de Ciências da Saúde do Distrito Federal, under CAAE registration number 93142318.7.0000.5553. The rules of Guideline 466/2012 of the National Health Council ${ }^{15}$ were followed.

\section{RESULTS}

Sample characterization

Three hundred and fifty-three questionnaires were included, which represents a response rate of $67.11 \%$. Of the assessed students, $51.37 \%$ were females and $48.63 \%$ were males. The mean age was 23.37 years. Most

REVISTA BRASILEIRA DE EDUCAÇÃO MÉDICA

3 44 (4) : e176; 2020 
students were single (91.45\%), lived with their parents $(69.48 \%)$ and did not have a job outside the college $(82.15 \%)$, in addition to practicing physical exercises (67.70\%), having leisure activities in their free time (79.04\%) and effective periods of rest in the last months (73.79\%). There was a similar distribution of the number of students participating in each year of the course. The sociodemographic profile of the students is shown in Table 1.

\begin{tabular}{|c|c|c|}
\hline Gender & $\mathbf{N}$ & $\%$ \\
\hline Female & 169 & 51.37 \\
\hline Male & 160 & 48.63 \\
\hline Total & 329 & 100.0 \\
\hline Marital status & $\mathrm{N}$ & $\%$ \\
\hline Single & 321 & 91.45 \\
\hline Married & 29 & 8.26 \\
\hline Divorced & 1 & 0.29 \\
\hline Total & 351 & 100.0 \\
\hline Residence & $\mathrm{N}$ & $\%$ \\
\hline With the parents & 239 & 69.48 \\
\hline With a relative & 37 & 10.75 \\
\hline With friends & 9 & 2.62 \\
\hline Alone & 59 & 17.15 \\
\hline Total & 344 & 100.0 \\
\hline Children & $\mathrm{N}$ & $\%$ \\
\hline Yes & 20 & 6.23 \\
\hline No & 301 & 93.77 \\
\hline Total & 321 & 100.0 \\
\hline Year attended in College & $\mathrm{N}$ & $\%$ \\
\hline $1^{\text {st }}$ year & 66 & 18.7 \\
\hline $2^{\text {nd }}$ year & 62 & 17.6 \\
\hline $3^{\text {rd }}$ year & 57 & 16.1 \\
\hline $4^{\text {th }}$ year & 63 & 17.8 \\
\hline $5^{\text {th }}$ year & 50 & 14.2 \\
\hline $6^{\text {th }}$ year & 55 & 15.6 \\
\hline Total & 353 & 100.0 \\
\hline Do you work outside the college? & $\mathrm{N}$ & $\%$ \\
\hline No & 290 & 82.2 \\
\hline Yes & 63 & 17.8 \\
\hline Total & 353 & 100.0 \\
\hline Were there justified absences (with a certificate) in the last 30 days? & $\mathrm{N}$ & $\%$ \\
\hline No & 320 & 92.2 \\
\hline Yes & 27 & 7.8 \\
\hline Total & 347 & 100.0 \\
\hline
\end{tabular}

Continue...

\begin{tabular}{|c|c|c|}
\hline \multicolumn{3}{|l|}{$\begin{array}{c}\text { Table } 1 \\
\text { Continuation }\end{array}$} \\
\hline Have you had effective periods of rest in the last 12 months? & $\mathbf{N}$ & $\%$ \\
\hline No & 92 & 26.2 \\
\hline Yes & 259 & 73.8 \\
\hline Total & 351 & 100.0 \\
\hline Do you do any leisure activities in your free time? & $\mathrm{N}$ & $\%$ \\
\hline No & 74 & 21.0 \\
\hline Yes & 279 & 79.0 \\
\hline Total & 353 & 100.0 \\
\hline Do you practice physical exercises? & $\mathrm{N}$ & $\%$ \\
\hline No & 114 & 32.3 \\
\hline Yes & 239 & 67.7 \\
\hline Total & 353 & 100.0 \\
\hline
\end{tabular}

Source: prepared by the authors.

\section{Differences between male and female genders}

Based on the performed analysis, 24 (14.20\%), female students and $26(16.25 \%)$ male students showed no altered dimensions, 97 (60.63\%) male students and $82(48.52) \%$ ) female students showed one of the three altered burnout dimensions. Thirty-two (20\%) male students and 55 (32.54\%) female students showed two altered dimensions, considered at increased risk for developing BS. Finally, 8 (4.73\%) female students and 5 (3.13\%) male students were diagnosed with Burnout Syndrome.

The association between the presence of altered BS dimensions with sociodemographic factors was also analyzed: gender, age, residence, children, year of college and paid work. A sociodemographic profile was established, in which increasing age and attending the last years of medical school contributed to an increased risk of developing BS for the female gender (CR2-F and CR3-F), while paid work, having children and living alone contributed to a reduced risk of BS. The sociodemographic factors that contributed to the increased risk of developing BS for the male gender (CR2-M and CR3-M) were age (the older the age, the greater the risk), attending the last years of school, paid work and living alone. Only the sociodemographic factor "having children" contributed to a reduction in the risk of the syndrome (Graph 1). Among the sociodemographic factors, "with whom they lived" showed the greatest association with the risk of developing BS for both genders (Graph 4).

\section{Predictive factors}

An analysis of the association between the predictive factors of Burnout Syndrome and the altered dimensions in the study participants was also performed, represented by fp1-4, with the results described in Graph 2. Among them, fp2 was the one with the highest association with the risk of BS development (Graph 3).

Predictive factors showed discrepant results between male and female individuals with two or more altered Burnout dimensions. Male students with at least two altered dimensions (CR2-M and CR3-M) did not feel valued and appreciated by the institution (fp4), but felt rewarded for the achieved objectives, hours of study and extracurricular activities (fp3). 


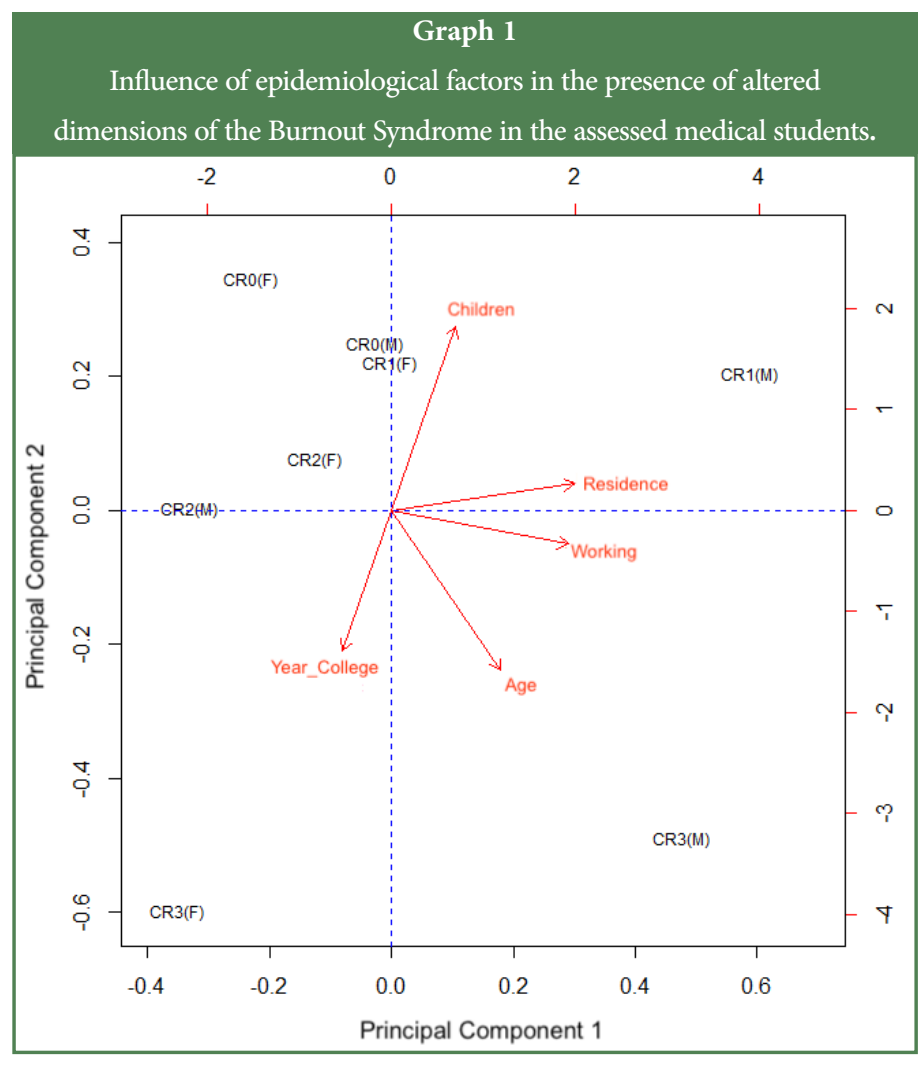

Source: prepared by the authors.

\section{Graph 2}

Influence of burnout predictors in medical students assessed by gender.

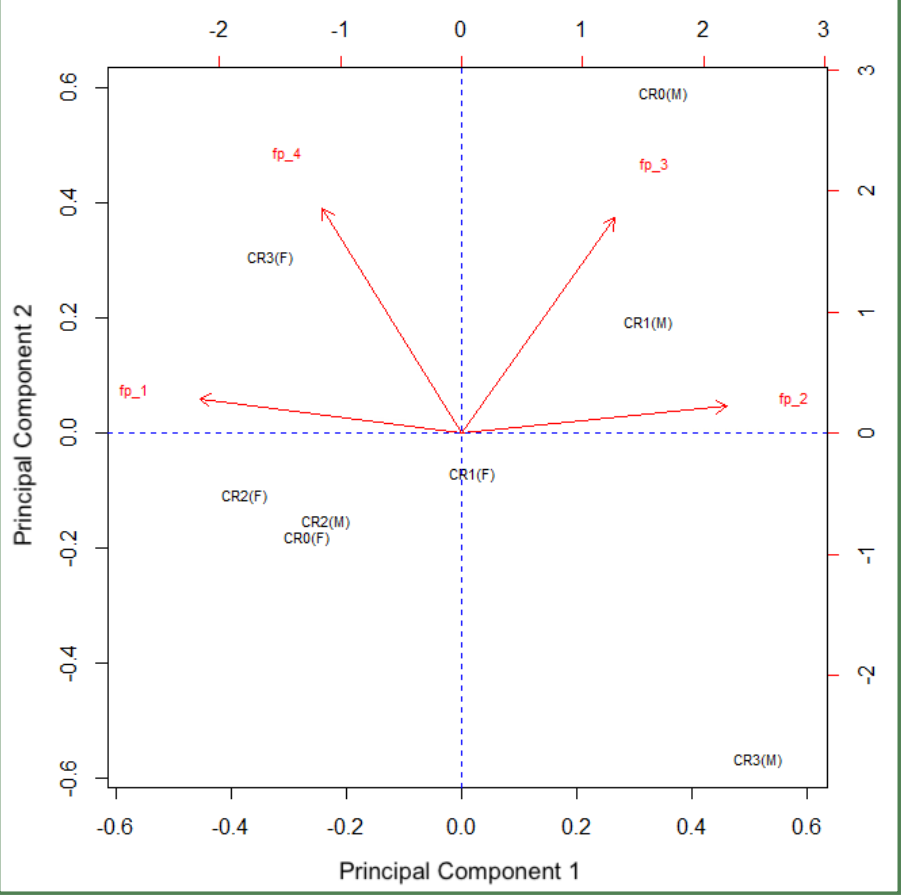

Source: prepared by the authors.

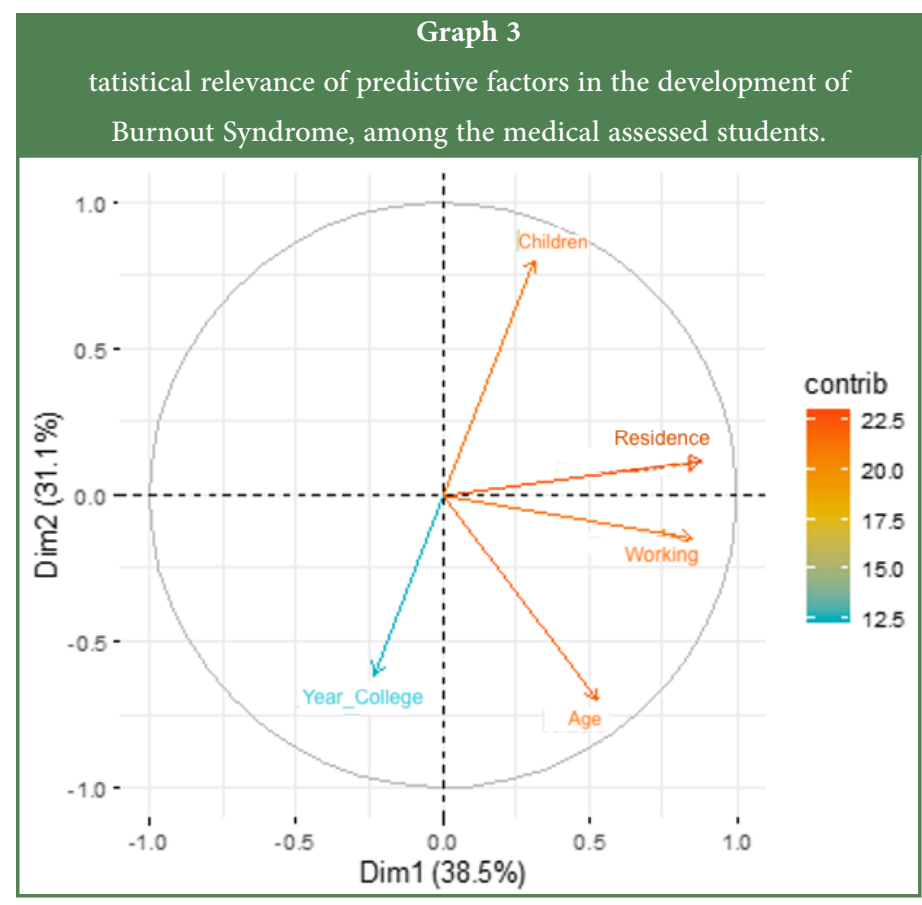

Source: prepared by the authors.

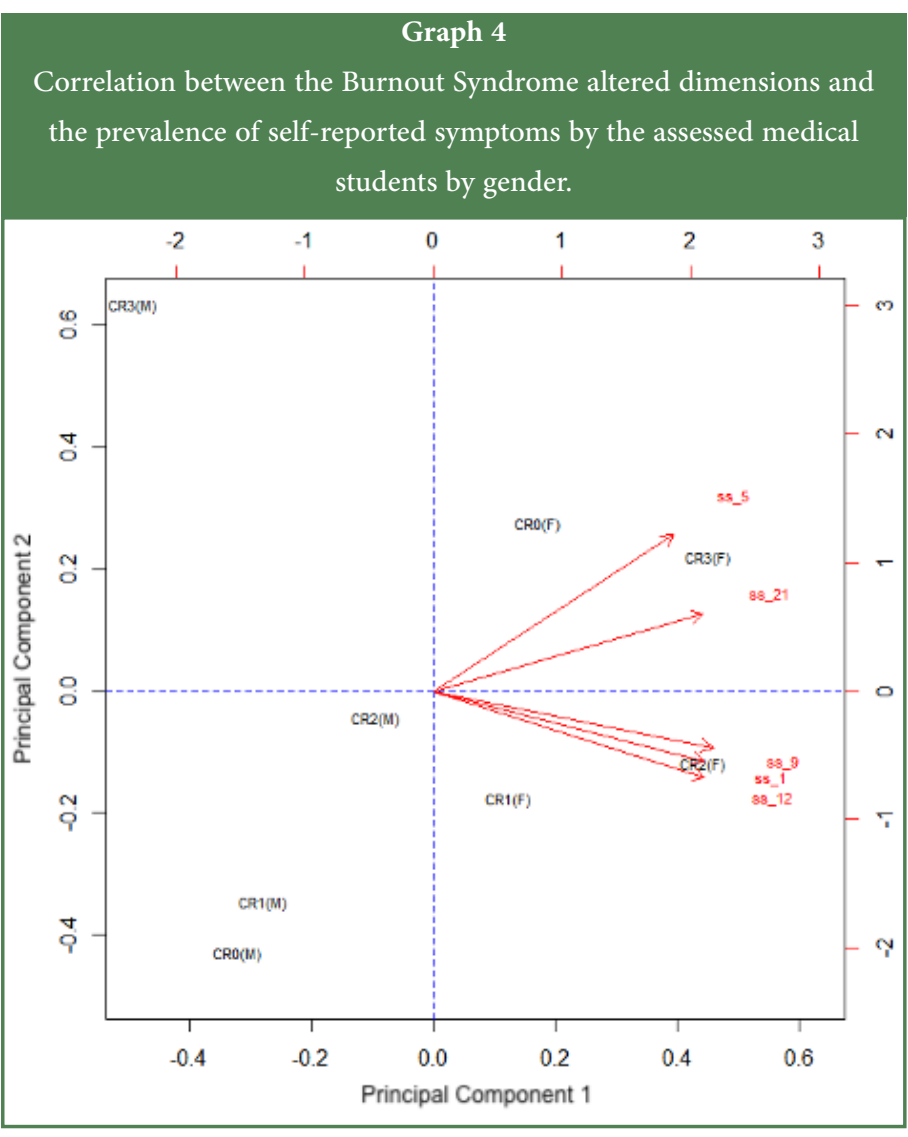

Source: prepared by the authors. 
They claimed to be able to control all their academic and institutional tasks (fp2) and did not believe that they were required more than they were capable of doing on a study day (fp1).

Female students with at least two altered dimensions, despite feeling that the institution was sensitive to the student, being appreciated and recognized by it (fp4), did not feel rewarded for the achieved objectives (fp3), hours of study and extracurricular activities. They stated that they were not able to control all their academic and institutional tasks (fp2) and believed that they were required more than it is possible to do on a study day.

\section{Self-reported somatic symptoms}

A correlation was made between the altered dimensions of BS and the prevalence of somatic symptoms self-reported by the study participants. The five most prevalent factors among students with two or more altered dimensions were: loss of sexual desire (ss21), sexual dysfunction (ss9), symptoms associated with minor infections (ss12), headache (ss1) and pain in the shoulders or neck (ss5). Female students, when compared to males, had a greater number of self-reported symptoms, with the main ones being headache and loss of sexual desire (Graph 4).

\section{DISCUSSION}

The prevalence of Burnout Syndrome in the present study was lower when compared to other cross-sectional studies with undergraduate medical students in Brazil, based on the MBI-SS scale, which a achieved a diagnosis between $11.4 \%$ and $19.6 \%$ of the students ${ }^{12,16}$. However, such studies used different forms of data analysis, using scores rather than percentiles to classify the dimensions as altered ${ }^{12}$. Moreover, these studies were carried out in universities that used the traditional teaching methodology and not the PBL method, which is different from the present study.

It should be noted that this study also included data analysis of students who were at high risk of developing BS, since they had two altered dimensions, showing a prevalence of $26.4 \%$. These data are in agreement with the study carried out at Universidade do Estado da Bahia ${ }^{16}$ in which $35.4 \%$ of the students were at high risk for BS. Both percentages showed the need for strategies to reduce the risk of BS, since this syndrome can impair the cognitive process necessary to acquire knowledge and skills ${ }^{17}$.

Still regarding the high risk found for BS, a large number of students with moderate and high levels of emotional exhaustion and feelings of depersonalization was observed in a study with first-year medical students ${ }^{18}$, also using the MBI-SS as an instrument.

Regarding the methodology used by the universities, a cross-sectional study carried out in Saudi Arabia in $2020^{19}$, with medical students attending between the $3^{\text {rd }}$ and $6^{\text {th }}$ years of medical school, did not observe any significant difference between students receiving problem-based vs. traditional learning. However, it is worth noting that the Copenhagen Burnout Inventory was used to assess the BS and not the MBI-SS, which is currently more often used ${ }^{20,21}$.

The results showed different perceptions between male and female students at increased risk of BS and with a diagnosis of the disorder. The women indicated that they did not feel rewarded for their academic efforts, unlike the male students. This finding can be a contributing factor for the development of BS in women and we admit that even when considered alone, it can contribute to a reduction in the quality of life. Lower quality of life scores, especially in the psychological domain, were identified in female students in a study carried out at Universidade Estadual do Rio de Janeiro, which used the World Health Organization Quality of Life (WHOQOL-bref) questionnaire as an instrument ${ }^{22}$.

Regarding the peculiarities of the female gender, a study carried out with students of Veterinary Medicine, based on MBI use, showed that women reported higher levels in the emotional exhaustion dimension ${ }^{23}$. Additionally, another study carried out at Faculdade de Medicina da Universidade do Porto found that female students had higher levels of academic stress ${ }^{24}$. These aspects corroborate those in our study, which demonstrated that women had a higher BS prevalence.

The male students, in turn, said they were able to control all their academic and institutional tasks and did not believe they were required more than they were capable of doing on a day of study. According to Gomes et $\mathrm{al}^{25}$, the pattern of masculinity and the culture of male virility makes the male gender reject behaviors that are stereotyped as female ones - verbalization of what they feel, search for care, physical and mental fragility - for fear of being seen as not manly or effeminate towards others, which would put their masculinity at risk. Therefore, male students may not recognize that they suffer from academic overload and report fewer symptoms when compared to the female students.

Studies on gender differences are controversial in the literature and should be analyzed with caution in order not to lead to conclusions about the supposed inferiority of one gender when compared to the other. A meta-analysis that evaluates the difference between genders in $\mathrm{BS}^{26}$ concluded that both genders suffer from BS, with women showing more changes in the dimension related to emotional exhaustion, while the alteration in the depersonalization dimension predominated in men.

Regarding the self-reported symptoms, a study carried out at Universidade Federal do Ceará ${ }^{27}$ with 200 medical students, found that women had higher levels of stress symptoms than men, based on Lipp's Stress Symptoms Inventory for Adults. Another study carried out in Pelotas, aiming at assessing the quality of life of young individuals, found that women had a higher prevalence of common mental disorders, which include symptoms such as irritability, difficulty concentrating, insomnia and somatic complaints $^{28}$. Such results are compatible with those found in this study.

In a literature review carried out by Mota et al. ${ }^{29}$ in 2017 on BS in students from the health area, it was verified that the level of stress and BS increased along with the course, with higher levels being identified in students who were in the last semesters. This statement corroborates the results of the present study. The author suggests three justifications for this finding: contact with patients; anxiety related to professional practice; and constant evaluation by teachers ${ }^{29}$.

Another cross-sectional study ${ }^{12}$ carried out using the MBI-SS instrument found that the younger the student, the higher the levels of emotional exhaustion and depersonalization, which is in disagreement with our results.

In this study, a higher prevalence of BS was identified in students of both genders who, in addition to studying, also had jobs outside the medical school. A study carried out with more than 500 medical students from 7 Peruvian universities found a similar result, indicating that those who performed extracurricular activities, such as working, showed stress more often, due to the greater burden of responsibilities ${ }^{5}$.

Another similar study justified these findings by the fact that working students had less time for study and leisure, which led to a higher level 
of stress in the long run ${ }^{30}$. We suggest that when work is associated with family support, it generates greater stress due to the need to seek income in periods other than those when attending college, thus limiting periods of study, leisure and rest. The jeopardizing of this time can interfere in the performance of school activities. This results in even greater psychological pressure to obtain positive academic results and the loss of self-management of the tasks assigned by the institution, as evidenced by the influence of the predictor factor 2 in the development of BS.

It can also be considered that having children increases the individual's responsibility and reduces their free time, which would increase the risk of developing BS. However, the result found in this study was different, showing that students with children did not have higher risks of Burnout Syndrome. This result is in line with other studies carried out among students in the health area ${ }^{30,1}$.

In a study carried out in the countryside of Minas Gerais, it was observed that among students with BS, there was a higher prevalence in those who lived with friends and, in the second place, in those who lived alone. Since this factor was important for the development of BS in the male gender, we suggest that living alone decreases the support network, increases the responsibility for taking care of one's home and decreases the student's free time. Therefore, it can contribute to the increased risk of BS.

\section{Study limitations}

Some limitations are present in this study. First, it is a cross-sectional study, which identified aspects present at a given moment, without performing a longitudinal analysis of the students' mental health. It can also have a bias related to the convenience sample, since students with a lower risk for BS and less stressed ones may have felt more apt to participate in the study and answer the questionnaires. Moreover, we did not obtain a $100 \%$ response rate from the students. Another limitation includes the lack of some sociodemographic data, such as the students' origin, ethnicity, family income, use of alcohol, illicit drugs and tobacco and previous psychiatric diagnoses, which could influence the outcomes found in the study. Thus, we suggest carrying out further studies in which these aspects are considered.

\section{CONCLUSION}

The prevalence of high risk of BS and its diagnosis found among medical students were $26.44 \%$ and $3.95 \%$, respectively.

Regarding the risk of developing BS, the predictor with the highest influence was the self-management of tasks proposed by the medical school. The sociodemographic data with the highest influence were: with whom the students lived, not having children, doing paid work and age. Differences were identified in the profiles of female and male students at high risk for BS, which could be explained by specific psychosocial profiles and justify further investigations on the subject.

Considering the obtained results, it was observed that the medical student was at high risk for Burnout Syndrome. Based on this, medical schools must value the students' mental health and seek adaptive strategies to deal with stress in the academic environment. The psychological support service is an example of a positive institutional tool for these cases.

It is worth mentioning that more studies are needed, especially longitudinal ones, aiming to establish effective strategies to reduce the prevalence of risk factors for Burnout Syndrome in medical students.

\section{ACKNOWLEDGEMENTS}

We thank the undergraduate students Eduarda Késsia Pereira da Silva, Tarcísio Vogel Júnior and Allyson Mikael Alves for their contribution.

\section{REFERENCES}

1. Almeida GC, Souza HR, Almeida PC, Almeida BC, Almeida GH. The prevalence of burnout syndrome in medical students. Arch Clin Psychiatry. 2016 Feb;43(1):6-10.

2. World Health Organization. International Classification of Diseases. WHO; 2019. Disponível em: https://icd.who.int/browse11/1-m/en. Access in 29 nov 2019.

3. Benevides-Pereira AMT, Gonçalves MB. Transtornos emocionais e a formação em Medicina: um estudo longitudinal. Rev Bras Educ Med. 2009;33(1):10-23.

4. Loureiro EMF, McIntyre TM, Mota-Cardoso R, Ferreira MA. Inventário de Fontes de Estresse Acadêmico no curso de Medicina (IFSAM). Rev Bras Educ Med. 2009;33(2):191-7.

5. Mejia CR, Garrido MJV, Ulfe LT, Arteaga KS, Rojas C, Arimuya JJR, et al. Síndrome de burnout y factores asociados en estudiantes de Medicina: estudio multicéntrico en siete facultades de medicina peruanas. Rev Chil Neuropsiquiatr. 2016;54(3):207-14.

6. Cornejo JV, Gutiérrez RH, Villalobos LA, Mariños CM, Maguiña $\mathrm{KM}$, Mallma NM, et al. Síndrome de burnout en estudiantes de medicina: frecuencia, características y factores asociados. Acta Med. 2016;33(4):282-8.

7. Ramos-Dias JC, Libardi MC, Zillo CM, Igarashi MH, Senger MH. Qualidade de vida em cem alunos do curso de Medicina de Sorocaba - PUC/SP. Rev Bras Educ Med. 2010;34(1):116-23.

8. Gómez PH, Pérez CV, Parra PP, Ortiz LM, Matus OB, McColl PC, et al. Relación entre el bienestar y el rendimiento académico en alumnos de primer año de medicina. Rev Med Chile. 2015;143(7): 930-7.

9. Campos JADB, Maroco J. Maslach Burnout Inventory - Student Survey: Portugal-Brazil cross-cultural adaptation. Rev Saude Publica. 2012;46(5):816-24.

10. Schuster MS, Dias VV, Battistella LF. Maslach Burnout Inventory General Survey (MBI-GS): aplicação em universidade pública federal. ReFAE. 2015;6(2):182-95.

11. Magnabosco G, Goulart CB, Haddad MCL, Vannuchi MTO, Dalmas JC. Síndrome de burnout em trabalhadores de um hospital público de média complexidade. Rev Min Enferm. 2009;13(4):506-14.

12. Chagas MKS, Moreira Junior DB, Cunha GN, Caixeta RP, Fonseca EF. Ocorrência da Síndrome de Burnout em acadêmicos de medicina de instituição de ensino no interior de Minas Gerais. Rev Med Saude Brasília. 2016;5(2):234-45.

13. $\mathrm{R}$ Core Team. R: A language and environment for statistical computing. Vienna: R Foundation for Statistical Computing; 2019. Available from: http://www.R-project.org/. Access in 04 jul 2018.

14. Santos GEO. Cálculo amostral: calculadora on-line [access in $11 \mathrm{mar}$ 2018]. Available from: http://www.calculoamostral.vai.la.

15. Brasil. Resolução CNS no 466, de 12 de dezembro de 2012. Aprova as diretrizes e normas regulamentadoras de pesquisas envolvendo seres humanos. Diário Oficial da União, Brasília; 13 jun 2013; v. 150, $\mathrm{n}^{\circ} 122$, p. 59-62 [access in 10 aug 2020]. Disponível: http://conselho. saude.gov.br/resolucoes/2012/Reso466.pdf. 
16. Aguiar RLB, Aguiar MCM, Merces MC. Síndrome de burnout em estudantes de medicina de universidade da Bahia. Rev Psi Divers Saúde. 2018;7(2):267-76.

17. McConnell MM, Eva KW. The role of emotion in the learning and transfer of clinical skills and knowledge. Acad Med. 2012;87:1316-22.

18. Medeiros MRB, Camargo JF, Barbosa LAR, Caldeira AP. Saúde mental de ingressantes no curso médico: uma abordagem segundo o sexo. Rev Bras Educ Med. 2018;42(3):214-21.

19. Al-Jehani YM, Althwanay AM, Buainain HM, Abuhaimed AK, Almulhim AM, Abusrir FA, et al. Burnout prevalence and associated stressors in medical students of traditional and problem-based learning curricula in a Saudi university. Saudi J Med Med Sci. 2020;8(2):125-32.

20. Pereira AMTB. Elaboração e validação do ISB: inventário para avaliação da síndrome de burnout. Bol Psicol. 2015;65(142):59-71. [access in 10 aug 2020]. Available from: http://pepsic.bvsalud.org/ scielo.php?script=sci_arttext \&pid=S0006-59432015000100006.

21. Moreno-Jiménez B. Evaluación, medidas e diagnóstico del síndrome del burnout. In: Gil-Monte PR, Moreno-Jiménez M, coordinadores. El síndrome de quemarse por el trabajo (burnout): grupos profesionales de riesgo. Madrid: Pirámide; 2007. p. 43-70.

22. Chazan ACS, Campos MR, Portugal FB. Qualidade de vida de estudantes de medicina da UERJ por meio do Whoqol-bref: uma abordagem multivariada. Cien Saude Colet. 2015;20(2):547-56.

23. Ilić Živojinović J, Backović D, Belojević G, Valčić O, Soldatović I, Janković J. Predictors of burnout among Belgrade veterinary students: a cross-sectional study. PLoS One. 2020;15(3):e0230685.

24. Loureiro E, Mcintyre T, Mota-Cardoso R, Ferreira MA. A relação entre o stress e os estilos de vida nos estudantes de Medicina da Faculdade de Medicina do Porto. Acta Med Port. 2008;21(3):209-14.

25. Gomes R, Nascimento EF, Araújo F. Por que os homens buscam menos os serviços de saúde do que as mulheres? As explicações de homens com baixa escolaridade e homens com ensino superior. Cad Saude Publica. 2007;23(3):565-74. doi: 10.1590/S0102-311X2007000300015.
26. Purvanova RK, Muros JP. Gender differences in burnout: a metaanalysis. J Vocat Behav. 2010;77:168-85.

27. Aguiar SM, Vieira APGF, Vieira KMF, Aguiar SM, Nóbrega JO. Prevalência de sintomas de estresse nos estudantes de Medicina. J Bras Psiquiatr. 2009;58(1):34-8.

28. Jansen K, Mondin TC, Ores LC, Souza LDM, Konradt CE, Pinheiro RT, et al. Transtornos mentais comuns e qualidade de vida em jovens: uma amostra populacional de Pelotas, Rio Grande do Sul, Brasil. Cad Saude Publica. 2011;27(3):440-8.

29. Mota ID, Farias GO, Da Silva R, Folle A. Síndrome de burnout em estudantes universitários: um olhar sobre as investigações. Motrivivência. 2017;29:243-56. Available from: https:// periodicos.ufsc.br/index.php/motrivivencia/article/view/21758042.2017v29nespp243/35497. Access in 06 sep 2019.

30. Reyes NB, Blanco NR. Prevalencia del síndrome de burnout académico en el estudiantado de Enfermería de la Universidad de Costa Rica. Enfermería Actual de Costa Rica. 2016;31:16-35. Available from: https://www.scielo.sa.cr/scielo.php?script=sci arttext\&pid=S1409-456820160002000160. Access in 06 sep 2019.

\section{AUTHORS' CONTRIBUTION}

The authors contributed equally to the writing of the article.

\section{CONFLICTS OF INTEREST}

The authors declare no conflicts of interest.

\section{ADDRESS FOR CORRESPONDENCE}

Alexandre Brandão Sé. SGAS 611, Centro Clínico Lúcio Costa, Bloco

2, Asa Sul, Brasília, DF, Brasil. CEP: 70200-700.

E-mail: alexandre.brs@gmail.com 